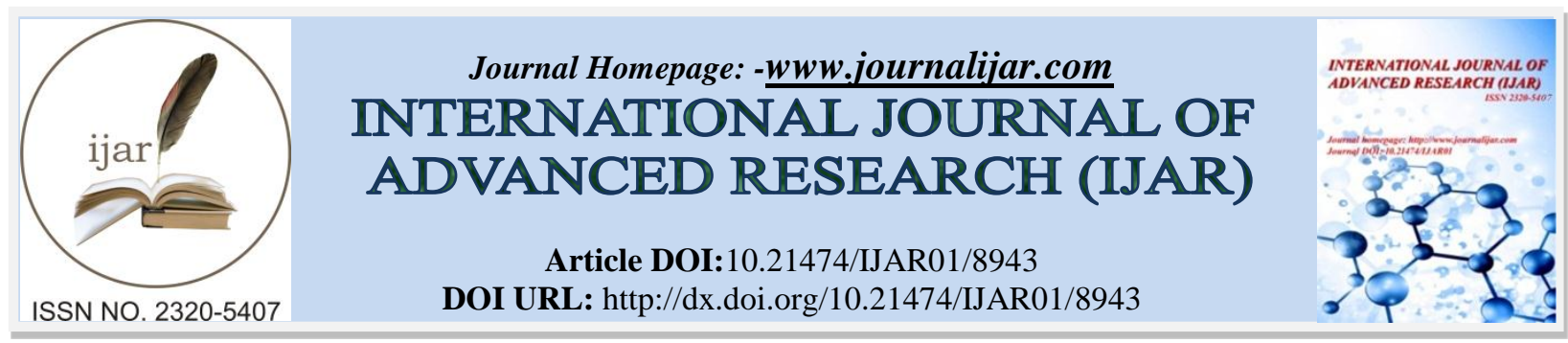

RESEARCH ARTICLE

\title{
FEMALE: THE CHANGE AGENT, EACH TIME A GIRL OPENS A BOOK AND READS A WOMANLESS HISTORY, SHE LEARNS SHE IS WORTH LESS 'MYRA POLLACK SADKER'.
}

Dr.Ekta Dhariwal.

Director, Arihant Educational Group Kota (Raj).

\section{Manuscript Info}

Manuscript History

Received: 22 February 2019

Final Accepted: 24 March 2019

Published: April 2019

\section{Key words:-}

International Women's Day (IWD), National Security Strategy Report (NSSR).

\section{Abstract}

It has been rightly said that the condition of a nation can be judged by looking at the status of its woman. God could not be everywhere so he created women to play their different roles then it may be mother, sister, daughter, wife or a friend. She holds multiple avatars. Time have changed, we have moved into a new era, where we have achieved and developed in a long way. But one of the thing that remains the same or close to truth, is the way women are always looked down upon in the society.

Women are always considered to be inferior to men. Today we are in $21^{\text {st }}$ century; girls are progressing in each and every field. We have so many examples where women have proved that if given an opportunity they are no less than any men. Kalpna Chawla, Saina Mirza, Siana Nehwal, Mary Kom, Pratibha Patil, Aishwarya Rai, P.T Usha, Kiran Bedi, Ekta Kapoor, Mother Teresa and the latest is Nikki Haley becoming first Indian- American to be appointed to the cabinet - level post in the US administration, list is endless which have proved their iron in their respective arenas. The main goal of this paper is to educate people about how much Indian women's roles have changed over the years.

Copy Right, IJAR, 2019,. All rights reserved.

\section{Introduction:-}

Throughout history, we have seen the effectiveness of women in resolving conflicts and affecting lasting change. Constitution has been an important tool to empower women in the fight for equal access to decision-making positions and governing bodies. Women understand that true security only comes with human and economic security, not just the presence of tanks and troops. Women's leadership is associated with access to clean drinking water, food, health care, shelter, education, and bodily integrity. All decision-makers should support global efforts to empower women and ensure their full and equal participation in all peace and security processes. [1]

Moving towards the turn of the century, it is now critical that women continue to reflect their experience in light of the theory that underpins organisational behaviour. By so doing, they will come to new meanings which will inform their future action.

In 1908, International Women's Day was celebrated for the first time."-Feminist Studies International Women's Day is on March 8th of every year since 1908. This is a day that celebrates women all over the world. It was first 
observed by women in Germany. As time moved on further into the 1900's, women were conquering more challenges and conflicts. During women's fight for more rights, the country was unwilling to accept that women wanted and expect more rights during this early time. By 1910, women started to look into and fight for the right to vote. This set forth the Women's Suffrage Movement. This is a movement that fights for women to have the right to vote. And after a long time, it turned out that woman are capable to do just as much, if not more, than some men can. The independence of women today have women landing themselves in positions in our career world that gives women just as much of a power status as any man. If there is a job out there, you can almost guarantee that there will be at least one woman, if not more than men on the work site. Some of these more manly worked jobs included doctors, lawyers, preachers, writers, and singers. These are great examples of changed attitudes towards the working woman, in the 21 rst century. A lot of careers that women are in and have today are still in clerical positions, factory work, and retail jobs. Over the last ten to fifteen years there has been a large rise in the number of women working outside the home.

Despite changing attitudes, major responsibility for childcare and housework generally lies with women which is the main reason why women are much more likely than men to be part-time workers. According to statistics and fact by Deirdre Hogan, $30 \%$ of female employees work part-time compared with $6 \%$ for men. And beings though part time work is lower paid, women are more likely to work for this lower pay cut. Even in full time work, there is still a considerable wage differential between men and women.

Over this past one hundred years, there have been a lot of attempts for equality, in hopes for women to live more fulfilled and equal lives with or without a lifelong partner. Because of how hard women of our yester years have worked, women today have just about all the choices in most household situations on whether they want to be a stay at home mom, or to be a nine to five working woman.

Another thing that has been happening since the beginning of men and women, and continues to happen to this day, is discrimination in many different forms. Types of discrimination would include sexual, physical, and the restriction of position in a job. Was it because women are looked at as the weaker sex? For a long time, before harassment and discrimination laws were passed. Women became accustomed and taught, before these laws, that because they were women and married that they could be treated however a spouse or an employer of the opposite sex wanted to. One in three women worldwide have experienced physical or sexual violence- mostly by an intimate partner. Whether at home, on the streets or during war, violence against women is a global pandemic that takes place in public and private spaces. Together we can and must end this pandemic. [2]

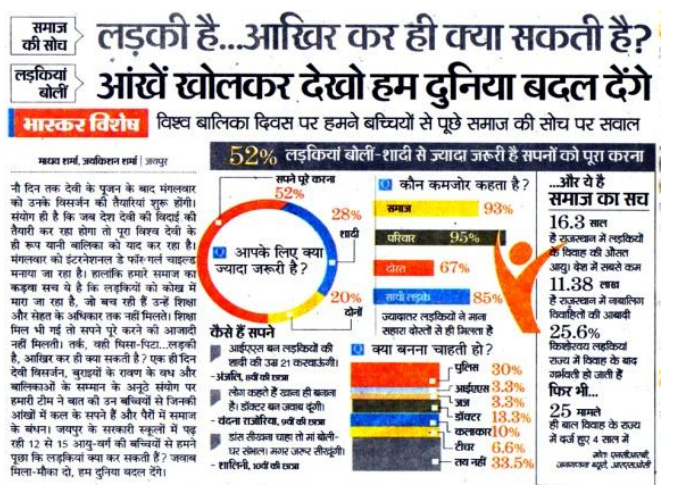

Figure 1:-yM+dh gS--- vkf[kj dj gh D;k ldrh gS\Dainik Bhaskar, Pp 12, Tuesday 11, Oct 2016

When first emerging into the 1900's, women were able to take limited career studies in college. These studies mainly included studies for nursing and teaching. An interesting fact about an extraordinary woman named Hellen Keller was that in 1904, even though she was the first deaf (could not hear) and blind (could not see) woman to graduate from college. This was a statement that if you put your mind to it, you can accomplish anything.-H.Keller. After many struggles to get the outside world to understand her and her intentions, HellenKeller succeeded. [3]

Moving through time into the 1930's, “in 1932, Amelia Earhart was the first woman to fly solo across the Atlantic Ocean."-100 Years of Progress. And by 1938, over 800,000 female workers had joined unions through their jobs for working in factories to help protect in discrimination situations. 
Moving into the 1940 's, women were finally able to join into military, but with strick stipulations. The military only accepted younger, unmarried women and they weren't at this time able to get into a job of authority to men.-100 Years of Progress. During the 1950's and 60's, women were beginning to find careers in the acting and modeling business. The Playboy magazine was introduced. Marylin Monroe was the first women centerfold in this magazine. So it seemed that men were in a sense starting to idolize woman and their beauty.

\section{The era of freedom has come for women and the society can't stop us to fly this time." "Stop being VICTIM and Take charge!"}

\section{Women's Political Participation}

Women everywhere continue to face challenges and barriers to productive participation in political engagement and government. In countries mired in conflict or cursed with poverty, the obstacles to overcome are even greater. Nevertheless, progress is occurring, but at a pace that is still too slow. Role in civil society, and government decision-making are key ingredients to building democracy. Democracy without the full participation of women is a contradiction in terms. It is a simple fact that no country can progress or prosper if half its citizens are left behind. Progress for women and progress for democracy go hand in hand.

Woman of the 21 st century are more independent. and it is not unheard of for a woman to live alone for a long amount of time. Women of the 21st century are more than willing to fight for what they want in today's constantly changing societies. Woman in America, are either bull headed, or very determined compared to some other cultures. In Indian culture, women are still waiting hand and foot for their husbands and are looked down upon if they do not comply with the cultural standards of where they live.

Since 1848, the world has witnessed innumerable popular organized movements for equal educational opportunities, equal political rights and economic equality for women. In the West, the status of women was enhanced by the conditions generated by the industrial revolution, humanitarian movements and women's movement for equality. In Asia and other countries which were not so industrially advanced, the change was brought about by reformers with a strong religious background.

During the last fifty to sixty years, the process of increasing women's participation in the economic, social and political life of their countries has been moving forward steadily. The success achieved by women in the twentieth century can only be described as phenomenal. Many women have achieved success in their various fields of endeavor - in social science, in business, in economics and in the political field. In some countries, women had even succeeded in capturing the top-most political appointments - as Prime Ministers of their lands - although ironically enough, in certain countries, women have yet to be given the franchise - the right to vote![4]

Today, investing in women is at the very heart of Indian policy. We know that women's participation is essential to addressing virtually every challenge we face as nations and as a community of nations. We are implementing policies and programs to grow women's leadership capacity in all areas of political participation and decisionmaking. The 2010 U.S. National Security Strategy Report that the Obama Administration just released notes that "experience shows that countries are more peaceful and prosperous when women are accorded full and equal rights and opportunity." We are investing in policies and programs to grow women's leadership capacity in all areas of political participation, decision-making, and civil society.

Women must not only be more engaged in governance, they must also be at the table in peace making, peace negotiations, and work on post-conflict reconstruction. We know that without the voices of women contributing to the delicate process of conflict resolution, peace is less likely to take root. We have seen, from Guatemala to Northern Ireland to Liberia to Afghanistan, that women can be powerful peacemakers, willing to reach across deep divides to find common ground. I have learned from the numerous women I have met around that one of the key needs women have is for leadership training programs that enable them to be more effective candidates from national to local levels of elected office. Moreover, because of obstacles to political power, women need stronger and broader networks and alliances to enhance the kind of participation that will enable them to surmount barriers. $[5]$

Women of India have always been highly active in politics, right from the early Vedic times such as Sati, Sita, Anasuya, Arundhatee, Draupadi, Queen Kunti, Shakuntala, Maitreyi, Gargi, Madalasa, Savitri, Ahalya, and others. It is said simply reciting their names removes sins. There are additional women from the last few hundred years 
whose lives we can recollect as well. Such great women have contributed to the glories and splendour of Vedic culture. In the Gupta period instances are not rare of women participating in administrative job. Prabhabati, the daughter of Chandra Gupta II performed administrative duties in her kingdom. [6]

Women were also allowed to explore martial pursuits. There are several references to women warriors, namely, Vadhrimati and Vishpala, in the hymn of the female seer Ghosha $(10.39,40)$. Both of them took part in actual fighting in the battlefield. We find another fighting woman in Shashiyasi (5.61.6, 5.61.9). Women warriors fought and died along with men, in one instance, Indra kills Danu, mother of Vritra, fighting by her son's side (Rig Veda 1.32.9).[7] Sarama, one of the most powerful woman warriors of her day was sent by her husband in search of robbers. She discovered their hiding place and killed them.

From Daulat Begum ,Badshah Begum, Jahanara Begum, Jija Bai, Razia Sultana to Sarojini Naidu, Vijaylakshami Pandit, Sucheta Kriplani who were the torchbearers for the women of India. The Sikh ranis (queens) occasionally took charge of state administration and their contribution to the Sikh polity as rulers. Regents, administrators and advisers has been creditable indeed. "The Sikh ladies ruled with vigour and diplomacy," says General Gordon. Rani Sada Kaur, Kanaihya, Mai Desan, Mai Sukhan. Dharam Kaur, these ladies were well known for their administrative acumen, grasp of political situations, and dexterity in handling arms and organising defence.

Mrs.Vijay Lakshmi Pandit was the first Indian woman to hold a post in the cabinet, thus paving the way for other women. The most important name in the category of women politicians of recent times is Mrs Indira Gandhi. She was the one who made world stop and notice the talent and potential of Indian women. She was the first women Prime Minister of independent India. Other women who have made their name in politics of India are Shiela Dixit, Uma Bharti, Jayalalitha, Vasundhra Raje, Mayawati and Mamata Banerjee.[8]

Our generation is accommodating more and more women in politics across the world - but even more significantly in the developed world. This is clearly because the developed world has a system that encourages and educates women to value civic engagement and helps them to see themselves as empowered leaders in politics and public policy. Studies conducted in the United States demonstrated that the public has more interest in women leaders. For instance, in a 2008 study it was found that the public would like to see more women in politics and public policy.

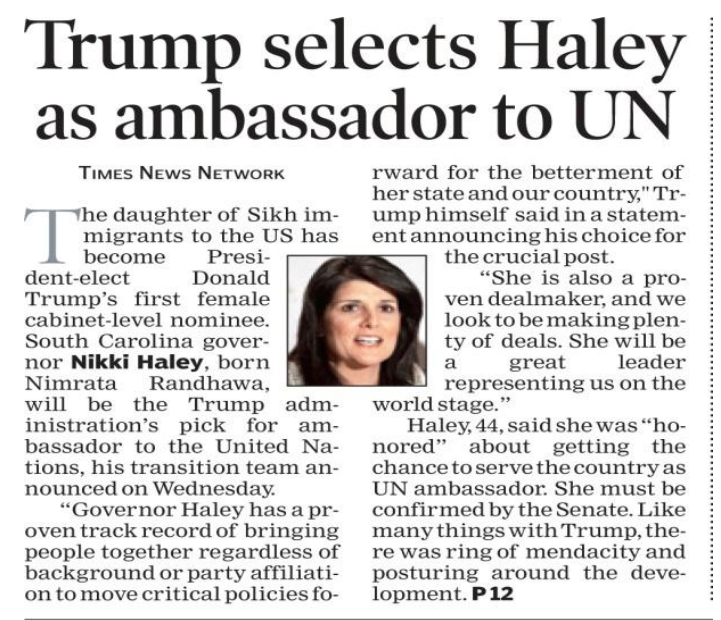

Figure 2:-Trump selects Haley as ambassador to UN Times of India Pp 01 Thursday 24, Nov. 2016

\section{Obstacles Faced By Women}

Reasons for the marginalisation of women in politics are not difficult to find. There are many obstacles to assimilation of women in the process of decision-making, operating at difficult levels. A very strong reason explaining women's limited participation has been the theory of women's "backward consciousness". However, as we saw earlier while analysing the women's role in non-formal mass movement, women have responded with great enthusiasm and responsibility on crucial occasions and do not necessarily suffer from "backward consciousness". Whether it is a movement against a foreign government, or a protest against vested interests in economic or political spheres, or a confrontation against the oppression landlords or contractor, women have not hesitated; they have made sacrifices and suffered repression along with men. 
The observation that women when elected do not participate in political activities is due to gender based division of labour in the family, women have to bear the full responsibility of household chores. Routine political campaign work, the necessity of maintaining contacts with the constituency, regular debates, discussion and meetings which are generally held at night usually clash with her household and other responsibilities. Moreover, speaking at public meeting, asserting her individuality and negotiating power bargains require training and experience, which are not easily accessible to women. Evidence is available that when women will all these burdens take up active work as party members or secretaries of a youth group, they suffer tremendous strain and tension. [9]

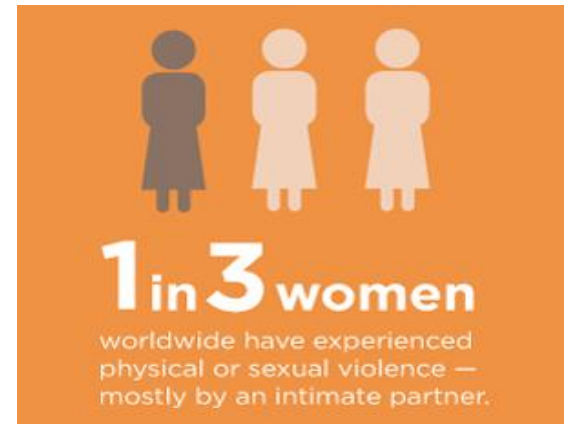

Figure 3:-Winifredd,(2015) November, 10 "Violence-against-women" https://gsijpoffice.com/infographic

Another equally significant deterrent is the current political culture. Not only has the political process become complicated, many decisions are taken behind the scene. Power games are controlled by monetary deals, and since women have little control over finance, they are not considered worth betting it.

Another important factor which has also be considered is that much of the political participation today requires information, knowledge, exposure to various experiments, strategies, models etc. In our country where only about 40 percent of women are literate, how can one expect women to participate effectively? The understanding of political processes, strategies and actions requires training, education and constant reaction. Even men in a poor illiterate society find it difficult to fulfil this requirement. It is a much more challenging task for women.

As a result of factors mentioned above, the participation of women in politics becomes limited to voting, organising processions and rallies and doing ancillary work in the party offices. [10]

\section{Women Is Decision Making}

The Universal Declaration of Human Rights recognizes the right of every person to take part in the government of his or her country. Equal access of men and women to power, decision-making and leadership at all levels is a necessary precondition for the proper functioning of democracy. Women's confidence and self-esteem increase when they have greater knowledge, economic assets and income-earning capacity, and they are more likely to participate in both private and public decision-making. Low participation is often due to stereotypes, perpetuated by both men and women, which assign women's influence to the private sphere and men's to the public. The use of quotas and positive action to increase women's participation in decision-making bodies is not enough to ensure their participation, but is an important first step. [11]

Achieving the goal of equal participation of women and men in decision-making will provide a balance that more accurately reflects the composition of society and is needed in order to strengthen democracy and promote its proper functioning. Equality in political decision-making performs a leverage function without which it is highly unlikely that a real integration of the equality dimension in government policy-making is feasible. In this respect, women's equal participation in political life plays a pivotal role in the general process of the advancement of women. Women's equal participation in decision-making is not only a demand for simple justice or democracy but can also be seen as a necessary condition for women's interests to be taken into account. Without the active participation of women and the incorporation of women's perspective at all levels of decision-making, the goals of equality, development and peace cannot be achieved. [12]

Women empowerment may be the key slogan for every government since independence, Girls are equally talented and if compared in many fields much better, superior and well ahead of men. The modern world nowadays is proud 
to acknowledge the equality that has been acknowledged between age, gender, and race. Women are treated equally with men. . [13] But the findings of a government report show women still lag way behind men in having a say in decision making and in their participation in economic activity.

The Central Statistics Office (CSO)'s publication "Women and Men in India 2014" found that women occupied seven out of 45 ministerial positions in the Narendra Modi's council of ministers, which is a little more than 15\%, against around $10 \%$ in 2004. In 2014 general election, only 62 females have been elected constituting more than $11 \%$ share in the $16^{\text {th }}$ Lok Sabha.

Though female participation in elections went up from 56\% in 15th Lok Sabha elections to $66 \%$ in the current one (16th Lok Sabha) in 2014, the male participation also improved from 60\% to 67\% during the same period. Out of 62 women parliamentarians, 20 are in the age group 41-50. As far as qualifications and professions go, $34 \%$ of the women MPs are social \& political workers and $44 \%$ post graduates. Among male members, the maximum (31\%) are from an agricultural background, $42 \%$ are graduates \& only $29 \%$ are postgraduates.

Women's participation is much less than desirable in states, where women have only an $8 \%$ share in legislative assemblies and 4\% in legislative councils as on August 2014.

In Panchayati raj institutions, overall $46.7 \%$ women are present with maximum 58.6\% in Jharkhand and minimum $32.3 \%$ in Goa as on 1st March, 2013. Observers felt that the better representation for women in local bodies is due to provision for $50 \%$ reservation.

In higher judiciary, there were only two women judges out of 30 in the Supreme Court. There were only 58 women judges out of 609 in different high courts with maximum 25\% in Delhi high court and no women judge in six high courts as on April, 2014. There were only five women judges out of 88 judges in Allahabad high court while only two against 32 in Andhra Pradesh high court and one against 29 in Kerala high court.

Women are at the receiving end as far as their representation in All-India and Central Group a Services are concerned. Only 14\% females were in Indian Administrative Service, 19\% in Indian Foreign Services and 12\% in Indian Trade Service. While data for Indian Police Services was not available, there were $30 \%$ females in Indian Economic Service and $28 \%$ in the Indian Forest Service. The report found that women constitute a little less than the half of the economically active population, but their contribution to economic activity is far low. As per Census 2011, the workforce participation rate for females is $25.51 \%$ against $53.26 \%$ for males. Rural areas have a better female workforce participation rate of $30.02 \%$ compared with $53.03 \%$ for males. In urban sector, the participation rate of females trails at $15.44 \%$ against $53.76 \%$ for males.

The report quoting NSSO survey indicated that the worker population ratio for females in rural areas was $24.8 \%$ and $54.3 \%$ for males in 2011-12, while in urban areas the ratio is 14.7 for females and 54.6 for males. The unemployment rate for women in rural area was $2.9 \%$ against $2.1 \%$ for men while it was $6.6 \%$ \& $3.2 \%$ for women \& men in urban areas during 2011-12. It was revealed that female participation in labour force has remained lower than male participation as most of the women remain engaged in unpaid work, and in case women are employed in paid work, it is mostly in the informal sectors . Women also face a significant wage differential vis-a-vis their male counterparts. [14]

When asked about the major obstacles faced by women in obtaining a decision-making or managerial position, $83.7 \%$ of women indicated childcare responsibilities as a barrier, while $82 \%$ of women cited the lack of partner support. More women than men stated that long working hours ( $75.8 \%$ of women, compared with $69.1 \%$ of men) and age (45.5\% of women, compared with $38 \%$ of men) represent significant obstacles for women in their pursuit of posts with greater responsibilities. About $30 \%$ of the survey respondents believed that women were disadvantaged due to their sex; this reason was given more often by women than men. [15]

At the beginning of the XII Five Year Plan and 63 years after women's rights were enshrined in the Constitution of India, there are several challenges remaining in fulfilling our constitutional commitments. Indian women continue to face discrimination in education, in jobs and in the remuneration they receive; their representation in public institutions is lower than that of men and violence against women in both public and the private spheres continues to be an area of concern. The XII Plan seeks to improve this situation by aligning its goal of achieving faster, more 
inclusive and sustainable growth to making women from all sections of society equal partners in the development process, thereby fulfilling their rights and meeting aspirations. In doing so, the XII Plan should make a strategic shift by making fulfilment of women's rights a condition to achievement of rapid and sustainable economic growth and according the highest priority to ending gender based inequities, discrimination and violence faced by girls and women.

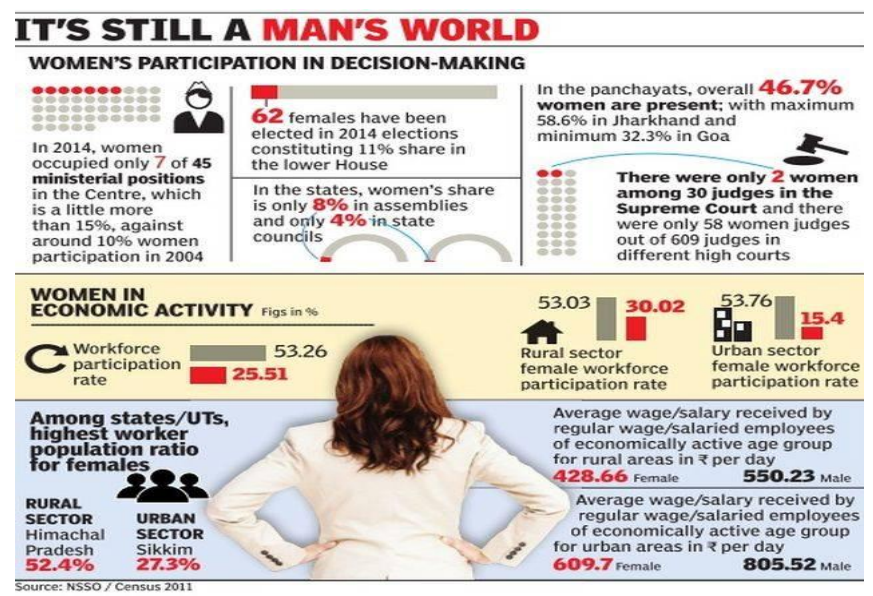

Figure 4:-Mahendra Singh (2014) TNN Nov 2, 06.13 AM IST “It's Still A Man's World”, 'Indian women hardly have any say in decision making' http://timesofindia.indiatimes.com/india/Indian-women-hardly-have-any-say-indecision-making/articleshow/45009555.cms

\section{Conclusion:-}

The status of women in modern India is a sort of a paradox. If on one hand she is at the peak of ladder of success, on the other hand she is mutely suffering the violence afflicted on her by her own family members. As compared with past women in modern times have achieved a lot but in reality they have to still travel a long way. Women have left the secured domain of their home and are now in the battlefield of life, fully armoured with their talent. They had proven themselves. But in India they are yet to get their dues. The sex ratio of India shows that the Indian society is still prejudiced against female. There are 943 females per 1000 males in India according to the census of 2016, which is much below the world average of 990 females.

However, the scene is now completely different from it in the past. After many revolutions for woman's rights, the role of the women is now respected and appreciated. As you can see, every woman can now decide their whole life. They choose their lover, decide their marriage; all parents' opinions now are only regarded as reference which the daughters can follow or not, which all are based on themselves. Moreover, until now, there are many laws that have been carried out to protect the role and the welfare of women; any illegal actions that rude and afflict women will be punished severely. Unlike women in the past whose place is inside the house, women in the 21 st century can be found everywhere: in the street, in the company and even in the construction site. They can run their own business without any restriction and even do it better than men.

For sure, those changes are imminent and all for the better future. Men and women, who are alike to be human beings, should be given the same rights, opportunities and treatments. As women can take part in business and jobs which were for man only, they make business and those jobs more effective by contributing their abilities and intelligence. Provided with freedom and protection, women will be able to have dreamed lives, develop their abilities and have fulfilment. The world, as a result, is peaceful and fair, free from discrimination.

\section{Acknowledgement:-}

I take this opportunity to acknowledge here the contributions and help rendered by many scholars in the completion of this research work. At the outset, I am highly grateful and indebted to Dr.Deepak Shriwastava Divisional Librarian (I/C) Govt. Divisional Public Library Kota (Rajasthan) who through his able guidance, comments and suggestions has helped me in the completion of this research study. He has been a source of constant encouragement and help right from the selection of the research topic till its completion. I wish to express my heartfelt thanks to Dr. Arvind Sexana Retd Vice Principal Government College Kota helping and especially for their criticism and valuable 
suggestions for this research paper. I don't find words to express my gratitude to my brother Mr Ankur Sucklecha, daughter Arsi Dhariwal and my parents. Without their love, moral support and constant encouragement this work would not have been possible.

I am thankful to all my friends who are there to stretch their hand for helping in all the time. It was their constant encouragement that made me to venture into its work.

I acknowledge the help of the staff of the library. They helped me in collecting data and necessary information for research work.

\section{Recommendation}

However, for women politicians to succeed in office, it is necessary to strengthen their capacity for leadership. It is also necessary that voters support them. Believing in women's experience to bring about wider social change and an end to inequality in particular, training for women who are running for office needs to ensure that women are willing and able to promote gender equality while governing.

Real freedom is freedom from all forms of bondage. It can be achieved only through proper spiritual development and purification of one's own mind - purging and cleansing oneself from all taints of greed, hatred and delusion. No amount of public debates, demonstrations and universal charters could bring true freedom - except through one's own diligence and heedfulness by the regular practice of meditation Actually Education is the keyword.

Women from rural area needs specific empowerment programme to enable them to be more autonomous in the household decision making. Women's autonomy by education, wealth quintile and development region needs a further social science investigation to observe the variations within each stratum. A more comprehensive strategy can enable women to access community resources, to challenge traditional norms and to access economic resources. This will lead the women to be more autonomous in decision making in the due course.

\section{References:-}

1. Jenkins Joni,(2014) Women as change agents http://www.courierjournal.com/story/opinion/contributors/12/24/women-change-agents/20859639/

2. Winifredd; November 6 /2016 "Violence against women," http://www.unwomen.org/en/digitallibrary/multimedia/2015/11/infographic-violence-against-womenInfo graphic

3. Women Hyperlink October $10 \quad / 2014 \quad / 15: 22$. Media and Technology http://www.womensorganizations.org/"'HYPERLINK

4. Jiteswori Naorem Devi, Kambhampati Subrahmanyam , Jun 2, 2015 "Women in the Rig Vedic age"https://www.google.co.in/\#q=Jiteswori+Naorem+Devi\%2C+Kambhampati+Subrahmanyam+\%2CWomen +in+the+Rig+Vedic+age.

5. Verveer.Melanna. (2010) "Government Efforts to Promote Women and Democracy Women as Agents of Change": Advancing the Role of Women in Politics and Civil Society http://www.state.gov/s/gwi/rls/rem/142953.htm\#

6. Mehta Bharat (2013) September 12, "Status of Women in Vedic Age "http://www.importantindia.com/2954/status-of-women-in-vedic-age/

7. Chaudhuri R. (2001 "Women's education in ancient India". In Madhavananda S, Majumdar RC, editors. Gt. Women f India. Fifth Empr. Kolkata: Advita Ashrama Mayawati, Champawat, Himalayas; 2001.Pp. 95101.http://www.mapsofindia.com/culture/indian-women.html

8. Shramshakti (1988) - Report of the National Commission on Self- Employed Women and Women in Informal sector New Delhi.

9. Neera Desai and Usha Thakkar; Women in Indian Society Pp. 112, 113, 114

10. Learning about strengthening decision-making https://www.ifad.org/topic/tools/tags/gender/gender/lessons/2592499

11. The United Nations Fourth World Conference on Women Beijing, China - September 1995 http://www.un.org/womenwatch/daw/beijing/platform/decision.htm

12. http://modiachievements.in/digital-india/girl-child-a-boon-or-a-bane

13. Mahendra Singh 'Indian women hardly have any say in decision making'http://timesofindia.indiatimes.com/india/Indian-women-hardly-have-any-say-in-decisionmaking/articleshow/45009555.cms

14. Debono Manwel (2007) July 15 "Barriers to women's participation in decision- making positions. 